sections was used to describe the elastic deformation and the deformation of the phase transformation. A numerical procedure for calculating a material diagram has been developed, which is a curve enveloping a family of material diagrams constructed for certain laws of change in the velocity of the deformation rupture front.

Conclusion. It is experimentally established that the behavior of the material at a point in the body in the General case differs from the behavior of the sample as a whole. The paper formulates a nonlinear phenomenological model to describe the properties of the material at the point. A diagram of a pseudoelastic material consisting of three nonlinear sections was used to describe the elastic deformation and the deformation of the phase transformation. This interpretation of the theory leads to an unstable stress-strain diagram and requires a solution of the boundary value problem taking into account the development of the transformation deformation front. This allowed from the standpoint of the proposed nonlinear model of the material to describe a number of experimental data on different samples under different loading conditions. A numerical procedure for calculating a material diagram has been developed, which is a curve enveloping a family of material diagrams constructed for certain laws of change in the velocity of the deformation rupture front. This allowed us to record the defining relations between the rates of stresses and strains in a universal form and to apply the known methods to solve specific nonlinear problems of thermo-pseudo-elastic-plasticity [1;2].

Keywords: phenomenological model, nonlinear model of material, materials with shape memory, thermo-pseudo-plasticity, numerical procedure of diagram calculation.

Одержано редакиією 04.03.2020 p. Прийнято до публікаиії 27.04.2020 p.

УДК 519.854

DOI 10.31651/2076-5886-2020-1-12-22

PACS 02.70.Wz

\section{LUKIANOV Petro,}

$\mathrm{PhD}$ in Physics and Mathematics, Senior

Researcher, Associate Professor, Department

ASOIU, Faculty of Information and

Computer Techniks, NTTU "KPI"

e-mail: luk_ptr@yahoo.com

ORCID: 0000-0002-7584-1491

MUKHA Iryna,

$\mathrm{PhD}$ in Technical Sciences, Associate

Professor, Deputy Head of the Department

ASOIU, Faculty of Information and

Computer Techniks, NTTU "KPI"

e-mail: mip_kpi@gmail.com

ORCID: 0000-0002-4423-5106

\title{
BOOLEAN FUNCTION “EXCLUSIVE OR” FOR THE N VARIABLES
}

This paper proposes a new Boolean function - "exclusive OR" for case of $n$ Boolean variables. The definition of this function is given; its basic properties are studied. In particular, it is established (theorem) that the "exclusive OR" of $n$ variable is a symmetric function with respect to the permutation of arguments, and in the case $n=2$ coincides with the "exclusive OR". For the cases $n=3 ; 4, a$ disjunctive normal form (DNF), perfect disjunctive normal form (PDNF), minimal disjunctive normal form are constructed. In particular, in the case of $n=3$, three equal minimal disjunctive normal forms were found using the Quine method. It is established that the conjunctive normal form, the perfect conjunctive normal form and the minimized conjunctive normal form coincide with the definition of the "exclusive OR" of $n$ variable. For the cases $n=3 ; 4$, Zhegalkin polynomials are constructed, which are of the order of one lower than PDNF. Post classification performed. It is established that the 
"exclusive OR" for the cases of $n=3.4$ belongs to the class $T_{0}$, does not belong to the classes $T_{1}$ and $L$, is not a monotonic and self-double function.

Keywords: Boolean function,"exclusive OR" of $n$ variables.

\section{Introduction}

Today in the theory of Boolean functions [1], [2] there is a known function,"exclusive OR". It looks like this:

$$
f\left(x_{1}, x_{2}\right)=x_{1} \oplus x_{2}=\bar{x}_{1} x_{2}+x_{1} \bar{x}_{2}=\left(\bar{x}_{1} \wedge x_{2}\right) \vee\left(x_{1} \wedge \bar{x}_{2}\right)
$$

in which the dash above means a logical "no", ie "马". In order to simplify the presentation further in this paper, the sign of Boolean multiplication and addition will be replaced by the usual multiplication and addition.

In the Venn's diagram [3] (Fig. 1), the function is denoted as two intersecting circles. The common part of these circles does not belong to the scope of this function. The remaining set is the domain of this function: left elements $\bar{x}_{2}$, but $x_{1}$, and right $\bar{x}_{1}$, but $x_{2}$. If we consider "exclusive OR" of three variables $x_{1}, x_{2}, x_{3}$ in one of the options:

$$
x_{1} \oplus\left(x_{2}+x_{3}\right) \text {, or } x_{2} \oplus\left(x_{1}+x_{3}\right) \text {, or } x_{3} \oplus\left(x_{1}+x_{2}\right),
$$

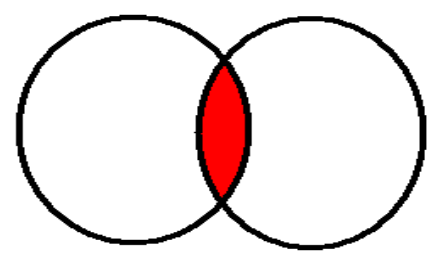

Fig. 1. Venn's diagram for the "exclusive or" of 2 variables

This type of function leads to the following expanded expressions:

$$
\begin{aligned}
& x_{1} \oplus\left(x_{2}+x_{3}\right)=\left(x_{1}+x_{2}+x_{3}\right)\left(\bar{x}_{1}+\bar{x}_{2} \bar{x}_{3}\right), \\
& x_{2} \oplus\left(x_{1}+x_{3}\right)=\left(x_{2}+x_{1}+x_{3}\right)\left(\bar{x}_{2}+\bar{x}_{1} \bar{x}_{3}\right), \\
& x_{3} \oplus\left(x_{1}+x_{2}\right)=\left(x_{3}+x_{1}+x_{2}\right)\left(\bar{x}_{3}+\bar{x}_{1} \bar{x}_{2}\right) .
\end{aligned}
$$

As can be seen from expressions (2), for a logical function of "exclusive OR" in the case of three logical variables such a symmetric expression as for the case of two variables (1) no longer exists. And we would very much like to. To solve this problem, we introduce a new Boolean function "exclusive OR" of $\mathrm{n}$ variables.

The aim of the study of the paper is Boolean function "exclusive OR" of $n$ variables and it properties.

\section{"Exclusive OR " for $n$ variables}

Let $X$ be a Boolean space, and let $x_{1}, x_{2}, \ldots, x_{n} \in X$ there be a set of Boolean variables.

Definition. "Exclusive OR" of $\mathrm{n}$ variables is the following Boolean function:

$$
f\left(x_{1}, x_{2}, \ldots, x_{n}\right)=\oplus_{1}^{n} x_{i}=\left(x_{1}+x_{2}+\ldots+x_{n}\right)\left(\bar{x}_{1}+\bar{x}_{2}+\ldots+\bar{x}_{n}\right) \text {. }
$$


The symbol $\oplus_{1}^{n} x_{i}$ hereafter will denote the Boolean "Exclusive OR" of $\mathrm{n}$ variables. OR".

Theorem 1. In the case of $n=2$, the "Exclusive OR" of $n$ variables is usual "Exclusive Proof. If we consider the case of a function of two variables $f\left(x_{1}, x_{2}\right)$, then expression (3) becomes:

$$
f\left(x_{1}, x_{2}\right)=\oplus_{1}^{2} x_{i}=\left(x_{1}+x_{2}\right)\left(\bar{x}_{1}+\bar{x}_{3}\right),
$$

that is, usual "Exclusive OR". The theorem is proved.

Theorem 2. "Exclusive OR" of $\mathrm{n}$ variables is a symmetric function with respect to permutation of arguments $x_{i} \rightarrow x_{j}$.

Proof. Indeed, if in formula (3) perform a permutation of any two arguments $x_{i} \rightarrow x_{j}$, the value of the function does not change. The theorem is proved.

Corollary of Theorem 2. Boolean "Exclusive OR" of $n$ variables is a symmetric function for any finite number of permutations of k-arguments $(k<n)$.

For a more detailed study of "Exclusive OR" of $n$ variables, consider two cases of the function $n=3 ; 4$. We construct a truth table for each of these cases, perfect disjunctive and conjunctive normal forms, find minimal forms and construct Zhegalkin polynomials, perform Post classification.

1. Case $n=3$

In this case, function (1) takes the expression:

$$
f\left(x_{1}, x_{2}, x_{3}\right)=\oplus_{1}^{3} x_{i}=\left(x_{1}+x_{2}+x_{3}\right)\left(\bar{x}_{1}+\bar{x}_{2}+\bar{x}_{3}\right)
$$

Table of truth in the case of $n=3$ has the following form:

\begin{tabular}{|l|l|l|l|l|l|l|l|l|l|l|}
\hline$x_{1}$ & $x_{2}$ & $x_{3}$ & $x_{1} \vee x_{2}$ & $x_{1} \vee x_{2} \vee x_{3}$ & $\bar{x}_{1}$ & $\bar{x}_{2}$ & $\bar{x}_{1} \vee \bar{x}_{2}$ & $\bar{x}_{3}$ & $\bar{x}_{1} \vee \bar{x}_{2} \vee \bar{x}_{3}$ & $\left(x_{1} \vee x_{2} \vee x_{3}\right)\left(\bar{x}_{1} \vee \bar{x}_{2} \vee \bar{x}_{3}\right)$ \\
\hline 0 & 0 & 0 & 0 & 0 & 1 & 1 & 1 & 1 & 1 & 0 \\
\hline 0 & 0 & 1 & 0 & 1 & 1 & 1 & 1 & 0 & 1 & 1 \\
\hline 0 & 1 & 0 & 1 & 1 & 1 & 0 & 1 & 1 & 1 & 1 \\
\hline 0 & 1 & 1 & 1 & 1 & 1 & 0 & 1 & 0 & 1 & 1 \\
\hline 1 & 0 & 0 & 1 & 1 & 0 & 1 & 1 & 1 & 1 & 1 \\
\hline 1 & 0 & 1 & 1 & 1 & 0 & 1 & 1 & 0 & 1 & 1 \\
\hline 1 & 1 & 0 & 1 & 1 & 0 & 0 & 0 & 1 & 1 & 1 \\
\hline 1 & 1 & 1 & 1 & 1 & 0 & 0 & 0 & 0 & 0 & 0 \\
\hline
\end{tabular}

Table 1. Table of truth in the case of $n=3$

If we perform the appropriate logical operations, we will have the following:

$$
\left(x_{1}+x_{2}+x_{3}\right)\left(\bar{x}_{1}+\bar{x}_{2}+\bar{x}_{3}\right)=x_{1} \bar{x}_{1}+x_{1} \bar{x}_{2}+x_{1} \bar{x}_{3}+x_{2} \bar{x}_{1}+x_{2} \bar{x}_{2}+x_{2} \bar{x}_{3}+x_{3} \bar{x}_{1}+x_{3} \bar{x}_{2}+x_{3} \bar{x}_{3}
$$

In the right-hand side of equation (4), expressions $x_{i} \bar{x}_{i}=0, i \leq 3$ are absorbed as mutually contradictory. In the end, only the following expression will remain: 


$$
f\left(x_{1}, x_{2}, x_{3}\right)=\oplus_{1}^{3} x_{i}=x_{1}\left(\bar{x}_{2}+\bar{x}_{3}\right)+x_{2}\left(\bar{x}_{1}+\bar{x}_{3}\right)+x_{3}\left(\bar{x}_{1}+\bar{x}_{2}\right),
$$

or

$$
f\left(x_{1}, x_{2}, x_{3}\right)=\oplus_{1}^{3} x_{i}=x_{1} \bar{x}_{2}+x_{1} \bar{x}_{3}+x_{2} \bar{x}_{1}+x_{2} \bar{x}_{3}+x_{3} \bar{x}_{1}+x_{3} \bar{x}_{2}
$$

Expression (6) is a disjunctive normal form that looks like known "Exclusive OR" $n=2$. Thus, the introduced function "Exclusive OR" of $n=3$ variables is in fact a generalization of the logical function "Exclusive OR" for the case of $n$ variables (in the case $n=3$ ). The Venn's diagram, based on (5) for this function, has the form of Fig.2.

1.1. A perfect disjunctive normal form is formed using the law of addition: $x_{i}+\bar{x}_{i}=1$ [4], [5]. So we have:

$$
\oplus_{1}^{3} x_{i}=x_{1} \bar{x}_{2}\left(x_{3}+\bar{x}_{3}\right)+x_{1} \bar{x}_{3}\left(x_{2}+\bar{x}_{2}\right)+x_{2} \bar{x}_{1}\left(x_{3}+\bar{x}_{3}\right)+x_{2} \bar{x}_{3}\left(x_{1}+\bar{x}_{1}\right)+x_{3} \bar{x}_{1}\left(x_{2}+\bar{x}_{2}\right)+x_{3} \bar{x}_{2}\left(x_{1}+\bar{x}_{1}\right)
$$

Perform logical multiplication operations:

$$
\begin{aligned}
& \oplus_{1}^{3} x_{i}=x_{1} \bar{x}_{2} x_{3}+x_{1} \bar{x}_{2} \bar{x}_{3}+x_{1} \bar{x}_{3} x_{2}+x_{1} \bar{x}_{3} \bar{x}_{2}+x_{2} \bar{x}_{1} x_{3}+x_{2} \bar{x}_{1} \bar{x}_{3}+x_{2} \bar{x}_{3} x_{1}+x_{2} \bar{x}_{3} \bar{x}_{1}+x_{3} \bar{x}_{1} x_{2}+ \\
& +x_{3} \bar{x}_{1} \bar{x}_{2}+x_{3} \bar{x}_{2} x_{1}+x_{3} \bar{x}_{2} \bar{x}_{1}
\end{aligned}
$$

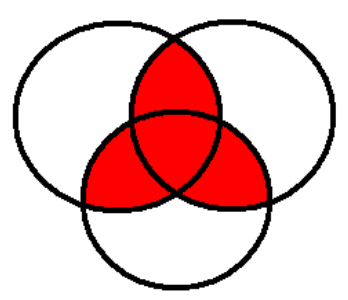

Fig. 2. Venn's diagram for the "Exclusive OR" of $n=3$ variables

In expression (7) we have twice the number of identical terms. According to the law of logical addition $x+x=x$, this expression is halved:

$$
\oplus_{1}^{3} x_{i}=x_{1} \bar{x}_{2} x_{3}+x_{1} \bar{x}_{2} \bar{x}_{3}+x_{1} \bar{x}_{3} x_{2}+x_{2} \bar{x}_{1} x_{3}+x_{2} \bar{x}_{1} \bar{x}_{3}+x_{3} \bar{x}_{1} \bar{x}_{2} \text {. }
$$

Expression (8) is a perfect disjunctive normal form (PDNF) of "Exclusive OR" of $\mathrm{n}=3$.

\subsection{Minimum DNF}

We find the minimum disjunctive normal form using the Quine's method. Construct a corresponding table with minterms of the third rank, included in the right part (8) of PDNF (table 2).

We have 6 implicants: $x_{3} \bar{x}_{2}, \bar{x}_{1} x_{3}, x_{1} \bar{x}_{2}, x_{1} \bar{x}_{3}, x_{1} \bar{x}_{3}, x_{2} \bar{x}_{1}$. Let's make a new table in which rows will be primary implicants, and columns coincide with minterms of PDNF. Put marks in those cells where the primary implicants are part of the corresponding minterm (table 3 ):

Since there are two marks in each column of the table, there are no significant implicants that could be removed from the table. Therefore, it remains to choose the minimum coverage at maximum intervals. As can be seen from table 2, there are 3 minimum DNF:

1) $f\left(x_{1}, x_{2}, x_{3}\right)=\oplus_{1}^{3} x_{i}=x_{1} \bar{x}_{2}+x_{1} \bar{x}_{3}+x_{2} \bar{x}_{3}+x_{3} \bar{x}_{1}$; 
2) $f\left(x_{1}, x_{2}, x_{3}\right)=\oplus_{1}^{3} x_{i}=x_{1} \bar{x}_{2}+x_{1} \bar{x}_{3}+x_{2} \bar{x}_{1}+x_{3} \bar{x}_{2}$

3) $f\left(x_{1}, x_{2}, x_{3}\right)=\oplus_{1}^{3} x_{i}=x_{1} \bar{x}_{2}+x_{1} \bar{x}_{3}+x_{2} \bar{x}_{1}+x_{3} \bar{x}_{1}$.

\begin{tabular}{|c|c|c|c|c|c|c|}
\hline & $x_{3} \bar{x}_{1} \bar{x}_{2}$ & $x_{1} \bar{x}_{2} x_{3}$ & $x_{1} \bar{x}_{2} \bar{x}_{3}$ & $x_{1} \bar{x}_{3} x_{2}$ & $x_{2} \bar{x}_{1} x_{3}$ & $x_{2} \bar{x}_{1} \bar{x}_{3}$ \\
\hline$x_{3} \bar{x}_{1} \bar{x}_{2}$ & 1 & $x_{3} \bar{x}_{2}$ & & & & $\bar{x}_{1} x_{3}$ \\
\hline$x_{1} \bar{x}_{2} x_{3}$ & $x_{3} \bar{x}_{2}$ & 1 & $x_{1} \bar{x}_{2}$ & & & \\
\hline$x_{1} \bar{x}_{2} \bar{x}_{3}$ & & $x_{1} \bar{x}_{2}$ & 1 & $x_{1} \bar{x}_{3}$ & & \\
\hline$x_{1} \bar{x}_{3} x_{2}$ & & & $x_{1} \bar{x}_{3}$ & 1 & & $x_{2} \bar{x}_{3}$ \\
\hline$x_{2} \bar{x}_{1} x_{3}$ & $\bar{x}_{1} x_{3}$ & & & & 1 & $x_{2} \bar{x}_{1}$ \\
\hline$x_{2} \bar{x}_{1} \bar{x}_{3}$ & & & & $x_{2} \bar{x}_{3}$ & $x_{2} \bar{x}_{1}$ & 1 \\
\hline
\end{tabular}

Table 2. Construction of minimum DNF by Quine's method

\begin{tabular}{|l|l|l|l|l|l|l|}
\hline & $x_{3} \bar{x}_{1} \bar{x}_{2}$ & $x_{1} \bar{x}_{2} x_{3}$ & $x_{1} \bar{x}_{2} \bar{x}_{3}$ & $x_{1} \bar{x}_{3} x_{2}$ & $x_{2} \bar{x}_{1} x_{3}$ & $x_{2} \bar{x}_{1} \bar{x}_{3}$ \\
\hline$x_{3} \bar{x}_{2}$ & $\vee$ & $\vee$ & & & & \\
\hline $\bar{x}_{1} x_{3}$ & $\vee$ & & & & $\vee$ & \\
\hline$x_{1} \bar{x}_{2}$ & & $\vee$ & $\vee$ & & & \\
\hline$x_{1} \bar{x}_{3}$ & & & $\vee$ & $\vee$ & & \\
\hline$x_{2} \bar{x}_{3}$ & & & & $\vee$ & & $\vee$ \\
\hline$x_{2} \bar{x}_{1}$ & & & & & $\vee$ & $\vee$ \\
\hline
\end{tabular}

Table 3. Marking

Since in expression (9) the number of variables, the number of objections and the number of terms are the same, the preference of any of the minimized DNFs cannot be given: each of 1) -3) minimized DNFs is equal.

\subsection{Perfect conjunctival normal form (PCNF), minimized CNF}

Since the procedure of Quine's method is also used to construct a minimized DCNF, as can be seen from the definition of "Exclusive OR" of $n$ variables (3), which is presented in the form of DCNF, none of the logical variables will be "absorbed". Therefore, DCNF and minimized CNF coincide directly with the definition (3) of "Exclusive OR" of $n$ variables.

\subsection{Zhegalkin polynomial for the case $n=3$}

According to the known theorem, each Boolean function of $\mathrm{n}$ variables can be represented as a Zhegalkin polynomial through logical operations conjunction and "Exclusive OR", $n=2$. Since for the case $n=2$ "Exclusive OR" of $n$ variables coincides "Exclusive OR", then the Zhegalkin polynomial is "Exclusive OR". For the case $n>2$ the Zhegalkin polynomial must be constructed. Construct a Zhegalkin polynomial for the case for $\mathrm{n}=3$ : 


$$
f\left(x_{1}, x_{2}, x_{3}\right)=\oplus_{1}^{3} x_{i}=a_{123} x_{1} x_{2} x_{3} \oplus a_{12} x_{1} x_{2} \oplus a_{13} x_{1} x_{3} \oplus a_{23} x_{2} x_{3} \oplus a_{1} x_{1} \oplus a_{2} x_{2} \oplus a_{3} x_{3} \oplus a_{0}
$$

We use the method of indefinite coefficients to find the unknown coefficients of the Zhegalkin polynomial. To find the coefficients use the truth table 1. Substitute the logical values $x_{1}, x_{2}, x_{3}$ of the variables corresponding to 0 and 1 , and equate the Zhegalkin polynomial for these values with the values of the function $f\left(x_{1}, x_{2}, x_{3}\right)$ from the truth table. Remember "Exclusive OR", which is present in the expression of the Zhegalkin polynomial, is equal to logical 1 only when the logical variables take opposite values, i.e. 0 and 1 . Otherwise, we have a logical 0.

$$
\begin{aligned}
& f(0 ; 0 ; 0)=0=0 \oplus a_{0} \Rightarrow a_{0}=0 ; \\
& f(0 ; 0 ; 1)=0=a_{3} \oplus a_{0}=1 \Rightarrow a_{3}=1 ; \\
& f(0 ; 1 ; 0)=0=a_{2} \oplus a_{0}, a_{0}=0 \Rightarrow a_{2}=1 ; \\
& f(0 ; 1 ; 1)=0=a_{23} \oplus a_{2} \oplus a_{3} \oplus a_{0}=1, a_{0}=0, a_{2}=1, a_{3}=1 \Rightarrow a_{23}=1 ; \\
& f(1 ; 0 ; 0)=a_{1} \oplus a_{0}=1, a_{0}=0 \Rightarrow a_{1}=1 ; \\
& f(1 ; 0 ; 1)=1=a_{13} \oplus a_{1} \oplus a_{3} \oplus a_{0} ; a_{0}=0, a_{1}=a_{3}=1 \Rightarrow a_{13}=1 ; \\
& f(1 ; 1 ; 0)=1=a_{12} \oplus a_{1} \oplus a_{2} \oplus a_{0} ; a_{0}=0, a_{1}=a_{2}=1 \Rightarrow a_{12}=1 ; \\
& f(1 ; 1 ; 1)=1=a_{123} \oplus a_{12} \oplus a_{13} \oplus a_{23} \oplus a_{1} \oplus a_{2} \oplus a_{3} \oplus a_{0} ; a_{0}=0, \\
& a_{1}=a_{2}=a_{3}=a_{12}=a_{13}=a_{23}=1, \Rightarrow a_{123}=0
\end{aligned}
$$

So, we have a Zhegalkin polynomial to "Exclusive OR" of $n=3$ in the following form:

$$
x_{1} \oplus x_{2} \oplus x_{3} \oplus x_{2} x_{3} \oplus x_{1} x_{2} \oplus x_{2} x_{3} .
$$

\subsection{Classification of Post}

1. "Exclusive OR" of $n$ variables, including $n=3$, on the zero set $f(0,0, \ldots, 0)=0$, therefore belongs to the class $T_{0}$;

2. "Exclusive OR" of $\mathrm{n}$ variables, including $n=3$, does not belong to the class $T_{1}$, since $f(1,1, \ldots, 1)=0 \neq 1$;

3. "Exclusive OR" of $n=3$ does not belong to the class of linear functions $L$, since the Zhegalkin polynomial for this case contains the products of variables.

4. "Exclusive OR" of $n=3$ does not belong to the class of monotonic functions, since for values $\{1\}$ and $\{0\}$ the condition of monotonicity is not fulfilled.

5. "Exclusive OR" of $n=3$ is not a self-double function as $f(0 ; 0 ; 0)=f(1 ; 1 ; 1)$, but condition $f(0 ; 0 ; 0) \neq f(1 ; 1 ; 1)$ must be satisfied.

2. Case $n=4$

For this case "Exclusive OR" of $n=4$ variables is the next:

$$
f\left(x_{1}, x_{2}, x_{3}\right)=\oplus_{1}^{4} x_{i}=\left(x_{1}+x_{2}+x_{3}+x_{4}\right)\left(\bar{x}_{1}+\bar{x}_{2}+\bar{x}_{3}+\bar{x}_{4}\right)
$$


Since the truth table for this case contains many columns, we construct a somewhat short truth table. In which part of the terms present in table 1 (case $n=3$ ) are omitted. The abbreviated truth table for function (12) has the form:

\begin{tabular}{|l|l|l|l|l|l|l|l|c|c|}
\hline$x_{1}$ & $x_{2}$ & $x_{3}$ & $x_{4}$ & $\bar{x}_{1}$ & $\bar{x}_{2}$ & $\bar{x}_{3}$ & $\bar{x}_{4}$ & $x_{1} \vee x_{2} \vee x_{3} \vee x_{4}$ & $\left(x_{1} \vee x_{2} \vee x_{3} \vee x_{4}\right)\left(\bar{x}_{1} \vee \bar{x}_{2} \vee \bar{x}_{3} \vee \bar{x}_{4}\right)$ \\
\hline 0 & 0 & 0 & 0 & 1 & 1 & 1 & 1 & 0 & 0 \\
\hline 0 & 0 & 0 & 1 & 1 & 1 & 1 & 0 & 1 & 1 \\
\hline 0 & 0 & 1 & 0 & 1 & 1 & 0 & 1 & 1 & 1 \\
\hline 0 & 0 & 1 & 1 & 1 & 1 & 0 & 0 & 1 & 1 \\
\hline 0 & 1 & 0 & 0 & 1 & 0 & 1 & 1 & 1 & 1 \\
\hline 0 & 1 & 0 & 1 & 1 & 0 & 1 & 0 & 1 & 1 \\
\hline 0 & 1 & 1 & 0 & 1 & 0 & 0 & 1 & 1 & 1 \\
\hline 0 & 1 & 1 & 1 & 1 & 0 & 0 & 0 & 1 & 1 \\
\hline 1 & 0 & 0 & 0 & 0 & 1 & 1 & 1 & 1 & 1 \\
\hline 1 & 0 & 0 & 1 & 0 & 1 & 1 & 0 & 1 & 1 \\
\hline 1 & 0 & 1 & 0 & 0 & 1 & 0 & 1 & 1 & 1 \\
\hline 1 & 0 & 1 & 1 & 0 & 1 & 0 & 0 & 1 & 1 \\
\hline 1 & 1 & 0 & 0 & 0 & 0 & 1 & 1 & 1 & 1 \\
\hline 1 & 1 & 0 & 1 & 0 & 0 & 1 & 0 & 1 & 1 \\
\hline 1 & 1 & 1 & 0 & 0 & 0 & 0 & 1 & 1 & 1 \\
\hline 1 & 1 & 1 & 1 & 0 & 0 & 0 & 0 & 1 & 1 \\
\hline
\end{tabular}

Table 4. Short truth table for the case $n=4$

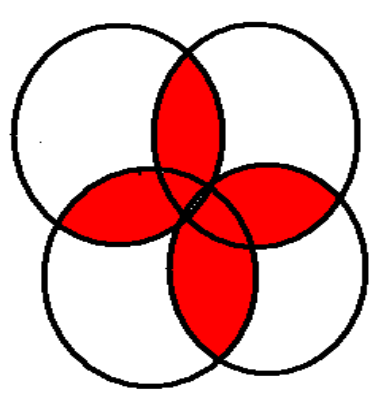

Fig. 3. Venn's diagram for the "Exclusive OR" of $n=4$ variables

Perform logical multiplication and addition, we have:

$$
\begin{aligned}
& \left(x_{1}+x_{2}+x_{3}+x_{4}\right)\left(\bar{x}_{1}+\bar{x}_{2}+\bar{x}_{3}+\bar{x}_{4}\right)= \\
= & x_{1}\left(\bar{x}_{1}+\bar{x}_{2}+\bar{x}_{3}+\bar{x}_{4}\right)+x_{2}\left(\bar{x}_{1}+\bar{x}_{2}+\bar{x}_{3}+\bar{x}_{4}\right)+x_{3}\left(\bar{x}_{1}+\bar{x}_{2}+\bar{x}_{3}+\bar{x}_{4}\right)+x_{4}\left(\bar{x}_{1}+\bar{x}_{2}+\bar{x}_{3}+\bar{x}_{4}\right) .
\end{aligned}
$$


After simplification of products of mutually contradictory variables we have:

$$
\begin{aligned}
& \oplus_{1}^{4} x_{i}=x_{1}\left(\bar{x}_{2}+\bar{x}_{3}+\bar{x}_{4}\right)+x_{2}\left(\bar{x}_{1}+\bar{x}_{3}+\bar{x}_{4}\right)+x_{3}\left(\bar{x}_{1}+\bar{x}_{2}+\bar{x}_{4}\right)+x_{4}\left(\bar{x}_{1}+\bar{x}_{2}+\bar{x}_{3}\right)= \\
& =x_{1} \bar{x}_{2}+x_{1} \bar{x}_{3}+x_{1} \bar{x}_{4}+x_{2} \bar{x}_{1}+x_{2} \bar{x}_{3}+x_{2} \bar{x}_{4}+x_{3} \bar{x}_{1}+x_{3} \bar{x}_{2}+x_{3} \bar{x}_{4}+x_{4} \bar{x}_{1}+x_{4} \bar{x}_{2}+x_{4} \bar{x}_{3} .
\end{aligned}
$$

Expression (13) is a disjunctive normal form of the "Exclusive OR" of $n=4$ variables.

\subsection{Perfect disjunctive normal form}

To get a perfect disjunctive normal form, apply the law of addition:

$$
\begin{aligned}
& x_{1} \bar{x}_{2}\left(x_{3}+\bar{x}_{3}\right)\left(x_{4}+\bar{x}_{4}\right)+x_{1} \bar{x}_{3}\left(x_{2}+\bar{x}_{2}\right)\left(x_{4}+\bar{x}_{4}\right)+x_{1} \bar{x}_{4}\left(x_{2}+\bar{x}_{2}\right)\left(x_{3}+\bar{x}_{3}\right)+x_{2} \bar{x}_{1}\left(x_{3}+\bar{x}_{3}\right)\left(x_{4}+\bar{x}_{4}\right)+ \\
& +x_{2} \bar{x}_{3}\left(x_{1}+\bar{x}_{1}\right)\left(x_{4}+\bar{x}_{4}\right)+x_{2} \bar{x}_{4}\left(x_{1}+\bar{x}_{1}\right)\left(x_{3}+\bar{x}_{3}\right)+x_{3} \bar{x}_{1}\left(x_{2}+\bar{x}_{2}\right)\left(x_{4}+\bar{x}_{4}\right)+x_{3} \bar{x}_{2}\left(x_{1}+\bar{x}_{1}\right)\left(x_{4}+\bar{x}_{4}\right)+ \\
& +x_{4} \bar{x}_{1}\left(x_{2}+\bar{x}_{2}\right)\left(x_{3}+\bar{x}_{3}\right)+x_{4} \bar{x}_{2}\left(x_{1}+\bar{x}_{1}\right)\left(x_{3}+\bar{x}_{3}\right)+x_{4} \bar{x}_{3}\left(x_{1}+\bar{x}_{1}\right)\left(x_{2}+\bar{x}_{2}\right)+x_{3} \bar{x}_{4}\left(x_{1}+\bar{x}_{1}\right)\left(x_{2}+\bar{x}_{2}\right)= \\
& =x_{1} \bar{x}_{2} x_{3} x_{4}+x_{1} \bar{x}_{2} \bar{x}_{3} x_{4}+x_{1} \bar{x}_{2} x_{3} \bar{x}_{4}+x_{1} \bar{x}_{2} \bar{x}_{3} \bar{x}_{4}+x_{1} x_{2} \bar{x}_{3} x_{4}+x_{1} \bar{x}_{2} \bar{x}_{3} x_{4}+x_{1} x_{2} \bar{x}_{3} \bar{x}_{4}+ \\
& +x_{1} \bar{x}_{2} \bar{x}_{3} \bar{x}_{4}+x_{1} x_{2} x_{3} \bar{x}_{4}+x_{1} \bar{x}_{2} x_{3} \bar{x}_{4}+x_{1} x_{2} \bar{x}_{3} \bar{x}_{4}+x_{1} \bar{x}_{2} \bar{x}_{3} \bar{x}_{4}+\bar{x}_{1} x_{2} x_{3} x_{4}+\bar{x}_{1} x_{2} \bar{x}_{3} x_{4}+ \\
& +\bar{x}_{1} x_{2} x_{3} \bar{x}_{4}+\bar{x}_{1} x_{2} \bar{x}_{3} \bar{x}_{4}+x_{1} x_{2} \bar{x}_{3} x_{4}+\bar{x}_{1} x_{2} \bar{x}_{3} x_{4}+x_{1} x_{2} \bar{x}_{3} \bar{x}_{4}+\bar{x}_{1} x_{2} \bar{x}_{3} \bar{x}_{4}+x_{1} x_{2} x_{3} \bar{x}_{4}+ \\
& +\bar{x}_{1} x_{2} x_{3} \bar{x}_{4}+x_{1} x_{2} \bar{x}_{3} \bar{x}_{4}+\bar{x}_{1} x_{2} \bar{x}_{3} \bar{x}_{4}+\bar{x}_{1} x_{2} x_{3} x_{4}+\bar{x}_{1} \bar{x}_{2} x_{3} x_{4}+\bar{x}_{1} x_{2} x_{3} \bar{x}_{4}+\bar{x}_{1} \bar{x}_{2} x_{3} \bar{x}_{4}+ \\
& +x_{1} \bar{x}_{2} x_{3} x_{4}+\bar{x}_{1} \bar{x}_{2} x_{3} x_{4}+x_{1} \bar{x}_{2} x_{3} \bar{x}_{4}+\bar{x}_{1} \bar{x}_{2} x_{3} \bar{x}_{4}+\bar{x}_{1} x_{2} x_{3} x_{4}+\bar{x}_{1} \bar{x}_{2} x_{3} x_{4}+\bar{x}_{1} x_{2} \bar{x}_{3} x_{4}+ \\
& +\bar{x}_{1} \bar{x}_{2} \bar{x}_{3} x_{4}+x_{1} \bar{x}_{2} x_{3} x_{4}+\bar{x}_{1} \bar{x}_{2} x_{3} x_{4}+x_{1} \bar{x}_{2} \bar{x}_{3} x_{4}+\bar{x}_{1} \bar{x}_{2} \bar{x}_{3} x_{4}+x_{1} x_{2} \bar{x}_{3} x_{4}+\bar{x}_{1} x_{2} \bar{x}_{3} x_{4}+ \\
& +x_{1} \bar{x}_{2} \bar{x}_{3} x_{4}+\bar{x}_{1} \bar{x}_{2} \bar{x}_{3} x_{4}+x_{1} x_{2} x_{3} \bar{x}_{4}+\bar{x}_{1} x_{2} x_{3} \bar{x}_{4}+x_{1} \bar{x}_{2} x_{3} \bar{x}_{4}+\bar{x}_{1} \bar{x}_{2} x_{3} \bar{x}_{4} \text {. }
\end{aligned}
$$

In expression (14) a significant number of terms are repeated. After absorbing the same logical terms, we finally have a perfect disjunctive normal form:

$$
\begin{aligned}
& \oplus_{1}^{4} x_{i}=x_{1} \bar{x}_{2} x_{3} x_{4}+x_{1} \bar{x}_{2} \bar{x}_{3} x_{4}+x_{1} \bar{x}_{2} x_{3} \bar{x}_{4}+x_{1} x_{2} \bar{x}_{3} x_{4}+x_{1} x_{2} \bar{x}_{3} \bar{x}_{4}+x_{1} \bar{x}_{2} \bar{x}_{3} \bar{x}_{4}+x_{1} x_{2} x_{3} \bar{x}_{4}+\bar{x}_{1} x_{2} x_{3} x_{4}+ \\
& +\bar{x}_{1} x_{2} \bar{x}_{3} x_{4}+\bar{x}_{1} x_{2} x_{3} \bar{x}_{4}+\bar{x}_{1} x_{2} \bar{x}_{3} \bar{x}_{4}+x_{1} x_{2} \bar{x}_{3} \bar{x}_{4}+\bar{x}_{1} \bar{x}_{2} x_{3} \bar{x}_{4}+\bar{x}_{1} \bar{x}_{2} \bar{x}_{3} x_{4} .
\end{aligned}
$$

\subsection{Minimum DNF}

As you can see, PDNF has 14 terms. Performing the procedure of finding the minimized DNF by the method of Quine leads to a cumbersome table, in which after the gluing procedure there are 16 minterms of the 3rd order. Of course, the presentation of Quine's algorithm in the format of this work is not convenient. Therefore, to obtain the minimum DNF, we will use Carnot maps.

According to the Carnot map method, we select rectangular areas from units of the largest area, which are powers of 2, and write the corresponding conjunctions for them: K1 $x_{1} \bar{x}_{2} ; \mathrm{K} 2-x_{1} \bar{x}_{3} ; \mathrm{K} 3-x_{1} \bar{x}_{4} ; \mathrm{K} 4-\bar{x}_{1} x_{2} ; \mathrm{K} 5-\bar{x}_{1} x_{3} ; \mathrm{K} 6-\bar{x}_{1} x_{4}$. Combining them with the help of logical addition we have a minimized DNF:

$$
x_{1} \bar{x}_{2}+x_{1} \bar{x}_{3}+x_{1} \bar{x}_{4}+\bar{x}_{1} x_{2}+\bar{x}_{1} x_{3}+\bar{x}_{1} x_{4}
$$


It is easy to see that, as in the case of $n=3$, the minimized CNF for the case of $n=4$ coincides with expression (12).

\begin{tabular}{|c|c|c|c|c|}
\hline$x_{1} x_{2} \backslash x_{3} x_{4}$ & 00 & 01 & 11 & 10 \\
\hline 00 & 0 & 1 & 1 & 1 \\
\hline 01 & 1 & 1 & 1 & 1 \\
\hline 11 & 1 & 1 & 0 & 1 \\
\hline 10 & 1 & 1 & 1 & 1 \\
\hline
\end{tabular}

Table 5. Minimization with Carnot maps

\subsection{Zhegalkin polynomial $n=4$}

We write Zhegalkin's polynomial in the form:

$f\left(x_{1}, x_{2}, x_{3}, x_{4}\right)=a_{1234} x_{1} x_{2} x_{3} x_{4} \oplus a_{234} x_{2} x_{3} x_{4} \oplus a_{134} x_{1} x_{3} x_{4} \oplus a_{124} x_{1} x_{2} x_{4} \oplus a_{134} x_{1} x_{3} x_{4} \oplus a_{123} x_{1} x_{2} x_{3} \oplus$ $\oplus a_{34} x_{3} x_{4} \oplus a_{24} x_{2} x_{4} \oplus a_{23} x_{2} x_{3} \oplus a_{14} x_{1} x_{4} \oplus a_{13} x_{1} x_{3} \oplus a_{12} x_{1} x_{2} \oplus a_{34} x_{3} x_{4} \oplus a_{24} x_{2} x_{4} \oplus a_{23} x_{2} x_{3} \oplus$ $\oplus a_{14} x_{1} x_{4} \oplus a_{13} x_{1} x_{3} \oplus a_{12} x_{1} x_{21} \oplus a_{4} x_{4} \oplus a_{3} x_{3} \oplus a_{2} x_{2} \oplus a_{1} x_{1} \oplus a_{0}$.

We will use the method of indefinite coefficients:

$f(0 ; 0 ; 0 ; 0)=a_{0}=0 \Rightarrow a_{0}=0 ;$

$f(1 ; 0 ; 0 ; 0)=a_{0} \oplus a_{1}=1, a_{0}=0 \Rightarrow a_{1}=1 ;$

$f(0 ; 1 ; 0 ; 0)=a_{0} \oplus a_{2}=1, a_{0}=0 \Rightarrow a_{2}=1 ;$

$f(0 ; 0 ; 1 ; 0)=a_{0} \oplus a_{3}=1, a_{0}=0 \Rightarrow a_{3}=1 ;$

$f(0 ; 0 ; 0 ; 1)=a_{0} \oplus a_{4}=1, a_{0}=0 \Rightarrow a_{4}=1 ;$

$f(1 ; 1 ; 0 ; 0)=a_{0} \oplus a_{1} \oplus a_{2} \oplus a_{12}=1, a_{0}=0, a_{1}=1, a_{2}=1 \Rightarrow a_{12}=1 ;$

$f(1 ; 0 ; 1 ; 0)=a_{0} \oplus a_{1} \oplus a_{3} \oplus a_{13}=1, a_{0}=0, a_{1}=1, a_{3}=1 \Rightarrow a_{13}=1 ;$

$f(1 ; 0 ; 0 ; 1)=a_{0} \oplus a_{1} \oplus a_{4} \oplus a_{14}=1, a_{0}=0, a_{1}=a_{4}=1 \Rightarrow a_{14}=1$;

$f(0 ; 1 ; 1 ; 0)=a_{0} \oplus a_{2} \oplus a_{3} \oplus a_{23}=1, a_{0}=0, a_{2}=a_{3}=1 \Rightarrow a_{23}=1$;

$f(0 ; 1 ; 0 ; 1)=a_{0} \oplus a_{2} \oplus a_{4} \oplus a_{24}=1, a_{0}=0, a_{2}=a_{4}=1 \Rightarrow a_{24}=1 ;$

$f(0 ; 0 ; 1 ; 1)=a_{0} \oplus a_{3} \oplus a_{4} \oplus a_{34}=1, a_{0}=0, a_{3}=a_{4}=1 \Rightarrow a_{34}=1$.

We take into account the found coefficients, without writing them once more, then we have:

$f(1 ; 1 ; 1 ; 0)=a_{0} \oplus a_{1} \oplus a_{2} \oplus a_{3} \oplus a_{12} \oplus a_{13} \oplus a_{23} \oplus a_{123}=1, \Rightarrow a_{123}=1 ;$

$f(1 ; 1 ; 0 ; 1)=a_{0} \oplus a_{1} \oplus a_{2} \oplus a_{4} \oplus a_{12} \oplus a_{14} \oplus a_{24} \oplus a_{124}=1 \Rightarrow a_{124}=1$; 


$$
\begin{aligned}
& f(1 ; 0 ; 1 ; 1)=a_{0} \oplus a_{1} \oplus a_{3} \oplus a_{4} \oplus a_{13} \oplus a_{14} \oplus a_{34} \oplus a_{134}=1 \Rightarrow a_{134}=1 ; \\
& f(0 ; 1 ; 1 ; 1)=a_{0} \oplus a_{2} \oplus a_{3} \oplus a_{4} \oplus a_{23} \oplus a_{24} \oplus a_{34} \oplus a_{234}=1 \Rightarrow a_{234}=1 ; \\
& f(1 ; 1 ; 1 ; 1)=a_{0} \oplus a_{1} \oplus a_{2} \oplus a_{3} \oplus a_{4} \oplus a_{12} \oplus a_{13} \oplus a_{14} \oplus a_{23} \oplus a_{24} . \\
& \oplus a_{34} \oplus a_{123} \oplus a_{124} \oplus a_{134} \oplus a_{234} \oplus a_{1234}=1 \Rightarrow a_{1234}=1
\end{aligned}
$$

After finding all the coefficients, we have the following form of the Zhegalkin polynomial:

$$
\begin{aligned}
& x_{1} \oplus x_{2} \oplus x_{3} \oplus x_{4} \oplus x_{1} x_{2} \oplus x_{1} x_{3} \oplus x_{1} x_{4} \oplus x_{2} x_{3} \oplus x_{2} x_{4} \oplus x_{3} x_{4} \oplus x_{1} x_{2} x_{3} . \\
& \oplus x_{1} x_{2} x_{4} \oplus x_{1} x_{3} x_{4} \oplus x_{2} x_{3} x_{4}
\end{aligned}
$$

As we can see from equations (11) and (17), the Zhegalkin polynomial is an order of magnitude lower than the the "Exclusive OR" : for $\mathrm{n}=3$ it is a second-order polynomial, and in the case of $\mathrm{n}=4$ it is a third-order polynomial.

\subsection{Post classification of "Exclusive OR", $n=4$}

1. $f(0 ; 0 ; 0 ; 0)=0$, therefore belongs to the class $T_{0}$;

2. $f(1,1,1,1)=0 \neq 1$, therefore does not belong to the class $T_{1}$;

3. Zhegalkin's polynomial for $\mathrm{n}=4$ contains the products of variables, so the "Exclusive OR" does not belong to the class of linear functions $L$;

4. "Exclusive OR" of $n=4$ does not belong to the class of monotonic functions: for values $\{1\}$ and $\{0\}$ the condition of monotonicity is not fulfilled;

5. "Exclusive OR" of $n=4$ is not a self-double function, since $f(0 ; 0 ; 0 ; 0)=f(1 ; 1 ; 1 ; 1)$.

\section{Conclusions}

1. In this paper, a new Boolean function is proposed - "exclusive OR" of n variables, its main properties are studied.

2. For cases $n=3,4$ the disjunctive normal form (DNF), the perfect disjunctive normal form (PDNF), the minimum disjunctive normal form are constructed. It is established that the conjunctive normal form, the perfect conjunctive normal form and the minimized conjunctive normal form coincide with the definition of "exclusive OR" of $n$ variables.

3. The classification of the Post is performed. It is established that the "exclusive OR" for $\mathrm{n}=3,4$ belongs to the class $T_{0}$, does not belong to the classes $T_{1}$ and $L$ is not monotonic and self-double.

\section{References:}

1. Bardachov, Yu. M., Sokolova, N. A., Khodakov, V. Ye. (2007). Discrete mathematics. - Kyiv: "Vysha shcola". - 384 p. [in Ukrainian]

2. Nikolsky, Yu. V., Pasichnyk, V. V., Scherbyna, Yu. M. (2007). Discrete mathematics. - Kyiv: BHV. 368 p. [in Ukrainian]

3. Borisenko, O. A. (2008). Discrete mathematics. - Sumy: "Universitetska knyga". - 256 p. [in Ukrainian]

4. Bondarenko, M. F., Bilous, N. F., Rutkas, A. G. (2004). Computer discrete mathematics. - Kharkiv: "Company SMIT". - 480 p. [in Ukrainian]

5. Kruvy, S. L. (2018). Problems on discrete mathematics. - Chernivtsy, Kyiv. - 456 p. [in Ukrainian]

\section{ЛУК'ЯНОВ Петро Володимирович,}

кандидат фізико-математичних наук, старший науковий співробітник НАН України, доцент, ACOIУ, ФIOТ, НТТУ “КПI” 
МУХА Ірина Павлівна,

кандидат технічних наук, доцент, заст. завідувача кафедри АСОІУ, ФІОТ, НТТУ “КПІ”.

\title{
БУЛЕВА ФУНКЦІЯ “ВИКЛЮЧАЮЧЕ АБО” ДЛЯ N ЗМІННИХ
}

Анотація. У даній роботі запропоновано нову булеву функиію - “виключаюче або” для $n$ змінних. Дано означення иієї функції, вивчено основні її властивості. Зокрема, встановлено (теорема), що “виключаюче або” є симетричною функцією відносно перестановки аргументів, а у випадку $n=2$ співпадає з додаванням за модулем 2. Для випадків $n=3 ; 4$ побудовано диз'юнктивну нормальну форму (ДНФ), досконалу диз'юнктивну нормальну форму (ДДНФ), мінімальну диз'юнктивну нормальну форму. Зокрема, у випадку $n=3$ за допомогою методу Квайна знайдено три рівноправних мінімальних диз'юнктивних нормальних форми. Встановлено, що кон'юнктивна нормальна форма, досконала кон'юнктивна нормальна форма та мінімізована кон'юнктивна нормальна форма співпадає з означенням “виключаюче або" для $n$ змінних. Для випадків $n=3,4$ побудовано поліноми Жегалкіна, які мають порядок на одиниџю нижче а ніж ДДНФ. Виконано класифікацію Поста. Встановлено, щуо “виключаюче або” для $n=3,4$ належить класу $T_{0}$, не належить класам $T_{1}$ та $L$, не є монотонною та само двоїстою функиісю.

Метою статті є введення нової функції “виключаюче або” для $n$ змінних та вивчення ї̈ основних властивостей.

Результати та висновки. У даній роботі запропоновано нову булаву функцію “виключаюче або” для $n$ змінних, вивчено основні ї̈ властивості. Для випадків $n=3 ; 4$ побудовано диз'юнктивну нормальну форму (ДНФ), досконалу диз'юнктивну нормальну форму (ДДНФ), мінімальну диз'юнктивну нормальну форму. Встановлено, що кон'юнктивна нормальна форма, досконала кон'юнктивна нормальна форма та мінімізована кон'юнктивна нормальна форма співпадає з означенням “виключаюче або” для $n$ змінних. Виконано класифікацію Поста. Встановлено, що додавання за модулем $n=3,4$ належить класу $T_{0}$, не належить класам $T_{1}$ та $L$, не є монотонною та самодвоїстою.

Ключові слова: булева функиія, “виключаюче або” для п змінних.

Одержано редакиією 20.02.2020 p. Прийнято до публікаиії 27.04.2020 p.

УДК 519.6

DOI $10.31651 / 2076-5886-2020-1-22-31$

PACS 02.60.-x, 02.60.Pn, 02.70.Wz

\section{ГОЛОВНЯ Борис Петрович,}

д.т.н., доцент, доцент кафедры прикладной математики и информатики Черкасского национального университета имени Богдана Хмельницкого e-mail: bpgolovnya@gmail.com ORCID 0000-0002-9242-3937

\section{РАСЧЕТ ЛАМИНАРИЗАЦИИ ТЕЧЕНИЯ ПРИ СОВПАДАЮЩЕЙ ТУРБУЛЕНТНОЙ СМЕШАННОЙ КОНВЕКЦИИ НА ВЕРТИКАЛЬНОЙ ПОВЕРХНОСТИ}

\begin{abstract}
Аннотация. На основе анализа уравнений турбулентной смешанной конвекиии предложены уравнения, описывающие изменение теплообмена в пограничном слое при наложении естественной конвекиии на вынужденную. По результатам расчетов смешанной конвекции были получены корреляционные зависимости для описания упомянутого снижения теплообмена. Расчеты по этим зависимостям находятся в удовлетворительном соответствии экспериментальным данным.
\end{abstract}

Ключевые слова: турбулентность ,смешанная конвекиия, ламинаризация течения. 